Revista do CESP, Belo Horizonte, v.34, n.52, p. 55-75, 2014

\title{
Poema-mundo: corpo-poema
}

\section{World-Poem: Body-Poem}

Dulcirley de Jesus

Universidade Federal de Minas Gerais (UFMG), Belo Horizonte, Minas Gerais, Brasil dulcirleyj@hotmail.com

Resumo: Entre os poemas de Herberto Helder em que há uma certa ênfase à relação entre as noções de mundo, de corpo e de linguagem, merece destaque Do mundo (2006), publicado pela primeira vez em 1978. Nele, há referências tanto a um mundo em gênese e formação quanto a um corpo orgânico que se move em seus processos de metamorfose. Todavia, tais imagens são produtos de uma construção que se dá por referências inconcretas. Estas, por sua vez, no devir de uma linguagem que irradia significações, enfeixam-se em um movimento de convergência que resulta em imagens como: o "corpo-poema", ou o "poema-corpo", e o "mundo-poema", ou o "poema/mundo"; ou ainda o corpo-mundopoema. Tais blocos de imagens materializam-se na poesia de Herberto Helder pelos processos de fusões, transmutações e de metamorfoses porque passam a linguagem, o que ocorre na mesma medida em que as palavras tornam-se coisa, corpo, mundo; corpo-mundo naquilo que esses espaços possuem de afinidade, como reitera Maffei: "Um profundo vitalismo, assim, faz a 'imagem' possuir características de corpos vivos e do próprio universo, por sua vez também um corpo vivo." Apesar da existência de uma comunicação intensa entre essas imagens nas duas obras, daremos ênfase, neste artigo, à leitura de Do mundo e sua relação com o espaço que the é homônimo com a palavra poética, já que, como é sugerido pelo próprio título, esse poema confere um tratamento especial à relação entre nome e coisa, palavra e realidade, linguagem e mundo.

Palavras-chave: Poema; mundo; corpo; linguagem.

${ }^{1}$ MAFFEI, 2007, p. 25. 
Abstract: Among Herberto Helder's poems that have emphasis in relation between the notions of world, body and language, the book Do mundo (2006), first published in 1978, deserves our attention. In this book, we could find references such in a world in genesis and formation as to a organic body that moves in their metamorphoses processes. However, these images are products of a construction that is not given by concrete references. These, in turn, in devir of a language that radiate meanings, reunites in a convergence movement that results in images such as: "body-poem", or "poem-body", and the "world-poem" or the "poem/ world"; or the body-world-poem. Such image blocks are materialized in the poetry of Herbert Helder by mergers process, transmutations and metamorphosis because they transpose the language, which occurs to the same extent that the words become thing, body, world; body-world in which these spaces have affinity, as Maffei reiterates: "A deep vitalism, thus, makes the 'image' possess characteristics of living bodies and the universe, itself, turns also a living body". Despite the existence of an intense communication between these images in both works, we will emphasize, in this article, the reading of Do Mundo and its relation with the namesake space with the poetic word, remembering, as suggested by the title itself, this poem gives special treatment to the relation between name and thing, word and reality, language and world.

Keywords: Poem; world; body; language.

Recebido em 22 de fevereiro de 2014. Aprovado em 05 de junho de 2014.

Trabalha naquilo antigo enquanto o mundo se move para o centro de si mesmo, como se todos os pontos em que trabalhas fossem o centro do mundo. Herberto Helder

\section{Das palavras ao corpo, do corpo ao mundo}

oema último que encerra o livro Ou o poema contínuo,
"Do mundo" parece ser o lugar onde o corpo alcança o
seu espectro espacialmente mais amplo, o que se deve ao 
modo como converge para a construção do que, segundo abordagem de Deleuze, seria um "grande pensamento". Diferente do que ocorre em O corpo o luxo a obra (2006), poema contínuo cujo centro energético parece estar na ideia de corpo orgânico, trata-se de uma poética marcada por divisões cujas partes comunicam-se entre si e com outros poemas da obra herbertiana, de modo que esse diálogo converge para a ideia de gênese. É nesse poema, por excelência, que o trânsito da ideia de corpo para a de mundo parece manifestar-se de forma mais expressiva, já que, no texto poético, o corpo genesíaco presente em $O$ corpo o luxo a obra retorna em um movimento em espiral e culmina na diluição dessa imagem que se confunde no fluxo das agitações, também orgânicas, do mundo. Como afirma Rosa Maria Martelo em "Corpo, Velocidade e Dissolução (De Herberto Helder a Al Berto)" (2001): o esvaziamento do eu, ou, no caso em questão, de uma forma, tem por produto final forças e energias que fazem de dada referência "uma espécie de palco onde os fluxos vitais

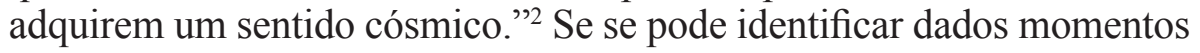
em que ocorre essa transmutação da imagem corpórea, entre outras situações, merece destaque a passagem da primeira parte do poema para a segunda, já que nesse limiar o corpo se rompe em abertura a uma série de poemas cujo centro energético parece ser um mundo em gênese e em vias de transformação.

Porque abalando as águas côncavas o acordou a lua e empurrou para fora, e ele estava amarrado pelo meio movendo os membros nos abismos do mundo, o espaço pulmonar do sangue, o espaço do sangue na cabeça, e depois disseram: está vivo! e bateram, cortaram, limparam, estiveram a ver esse pedaço de matéria fechada, a matéria vibrante aberta nos orifícios intensos, vivo!, disseram, aquele que um dia, a mão sobre a mesa em cada linha celular, a potência refluxa da mesa na mão por ele dentro, e já ninguém batia e cortava e soprava e fechava e abria, ninguém com o tremor das teias de sangue na cabeça, as teias de seiva na mesa, e a mão em cima, e ele passava

${ }^{2}$ MARTELO, 2001, p. 50. 
do mais profundo para o mais leve na obscuridade, o mais absoluto, ninguém que dissesse: as águas exaltadas, aura, e ele era impelido por entre os renques de luz plenamente.

Nesses versos, o corpo reporta àquele que se desenvolve em condições similares em $O$ corpo o luxo a obra, já que ambos são submetidos à mesma violência, "e bateram, cortaram, limparam”, bem como a dadas situações que os aproximam, como o modo como se confundem com a ideia de obra poética e de mundo. A referência à mesa, por exemplo, abre lugar à leitura do metatexto por comportar, em $\mathrm{HH}$, a noção de exercício alimentar, e, metaforicamente, de espaço que remonta ao trabalho do poeta. Isto é, o ritual alimentar aproxima-se ao gesto da escrita, na medida em que este requer, ao modo daquela experiência, a devoração, a deglutição e todos os processos de transformação porque passam o alimento até transformar-se em matéria outra. Em A lógica do sentido (2009), Deleuze prevê a relação entre pensamento e alimentação:

\begin{abstract}
É no verbo na sua univocidade que conjuga devorar e pensar, comer e pensar, comer que ele projeta sobre a superfície metafísica e pensar que nela desenha. E porque comer não é mais uma ação, nem ser comido uma paixão, mas somente o atributo noemático que lhes corresponde no verbo, a boca fica como que liberada para o pensamento que a preenche com todas as palavras possíveis. O verbo é, pois, falar, que significa comer-pensar na superfície metafísica e que faz com que $\mathrm{o}$ acontecimento sobrevenha às coisas consumíveis como o exprimível da linguagem e que o sentido insista na linguagem como a expressão do pensamento. Pensar significa, pois, da mesma forma comer-falar, comer como "resultado", falar como "tornado possível."3
\end{abstract}

A devoração do alimento, na perspectiva de Deleuze, portanto, relaciona-se à devoração da palavra. À ressignificação desta, a qual manifesta-se como expressão do pensamento que se dá pela fala, ou pela escrita. Falar-escrever, nesse sentido, é o resultado da deglutição da palavra, o "tornado possível". Relação essa que se manifesta com

${ }^{3}$ DELEUZE, 2009, p. 248. 
certa recorrência na poética herbertiana e que ganha destaque em um livro de $\mathrm{HH}$, cujo título comunica com essa perspectiva de forma até mesmo direta. Trata-se de $A$ colher na boca (2006), obra em que o ritual alimentar ganha destaque. Nela, a imagem da mesa, juntamente com outras referências que compõem a cena da alimentação - como a colher, o garfo, a faca, as frutas - adquire grande valor significativo por configurar-se como componente essencial àquilo que converge para a noção de metatexto. São várias as referências em que o substantivo mesa aparece, direta ou indiretamente (como por metonímias) relacionado à noção de exercício poético, como em: "A colher, de súbito cai no silêncio da língua"; "A colher subia como um instrumento da criação"; "Todas as coisas são mesa para os pensamentos".

$$
\begin{aligned}
& \text { e as luzes e as trevas em volta da mesa } \\
& \text { e a força sustida das coisas } \\
& \text { e a redonda e livre harmonia do mundo. }[\ldots] \\
& \text { - E o poema faz-se contra a carne e o tempo; }
\end{aligned}
$$

Nesses versos, o exercício poético, assim como propõe Deleuze, é associado à ideia de alimento que, por sua vez, se relaciona à noção de mutação, de alquimia, de metamorfose e de criação. Estabelece-se, dessa forma, um paralelismo que se configura como uma chave de leitura em HH: o algo ser "mesa para o pensamento" e o nome, a referência, ser alimento para a expressão poética. Nesse caso, a referência à mesa, objeto que sugere o espaço destinado ao início do processo de transformação do alimento no momento da digestão, metaforiza o ritual da criação poética que, assim como no processo alimentar, envolve complexas reações "metabólicas".

No prefácio de Edoi Lelia Doura... o próprio Herberto Helder corrobora com a perspectiva aqui apresentada ao associar o exercício poético à ideia de alimentação:

Como ressalta então o recôndito, o lugar onde a carne é comida, e ressurge, mercê da aliança da linguagem com as formas! Não se discorre. A vitalidade nominal é intrínseca, metabólica: pode tender para o silêncio ou tomar o ganho de uma voz, mas não explica, age apenas, age como substância, forma e nome da realidade. Vejo eu mesmo, à

${ }^{4}$ HELDER, 2006, p. 62; 63; 15; 23. 
custa de operações secretas - alimentos, silêncios - [...] um combate com as armas inocentes e astuciosas da magia, carne contra carne, imagens, sopro, os terríveis substantivos da terra, objectos vivos. ${ }^{5}$

A mesa, no poema supracitado, é, portanto, o espaço da produção artística. O lugar onde a mão "em cada linha celular" opera na "potência refluxa" que o exercício poético permite alcançar e reúne corpo, poesia e mundo no ritual de uma devoração que é física, alquímica e também estética.

Em seu artigo "Corpo, Velocidade e Dissolução (De Herberto Helder a Al Berto)", Rosa Maria Martelo reitera esse elo comunicante entre corpo, obra e mundo ao "Situar metonimicamente o poema como uma amostra-de-mundo [que] pressupõe o desinteresse por uma lógica de representação", bem como ao conceber o corpo como "o lugar de uma profundíssima cumplicidade ontológica com o universo." Ainda segundo Martelo,

[...] as insistentes referências de Herberto Helder às aberturas do corpo - as narinas, a boca, a vagina, o ânus, os poros - frequentemente em contextos onde encontramos também referências ao ouro, de evidentes conotações alquímicas, bem como as inúmeras referências às artérias, ao fluxo sanguíneo e às vísceras derivam desta correlação [do corpo com o mundo]. Trata-se de uma visão aproximal da visão esotérica do corpo, a qual pressupõe a anatomia subtil, isto é, o entendimento do corpo como um lugar percorrido por energias subtis e análogas ao cosmos. É neste contexto que entende-se [...] o modo fragmentado como o corpo é referido em Herberto Helder. Este processo de desagregação do corpo supõe um sujeito que participa da essência das coisas e que, por isso, é reconduzido à unidade primordial. "Enquanto duplos microcósmicos do macrocosmos os nossos corpos contêm todas as energias do universo" (Gil, 1997:92) e, no quadro desse entendimento, a dissolução da identidade não constitui exactamente uma perda porque releva de um estado unitivo com o todo $[\ldots] .{ }^{.7}$

\footnotetext{
${ }^{5}$ HELDER, 1985, p. 7.

${ }^{6}$ MARTELO, 2001, p. 55; 52.

${ }^{7}$ MARTELO, 2001, p. 52-53.
} 
Essa perspectiva de Martelo justifica, de certa maneira, o modo como as referências e imagens da primeira parte de Do mundo se enfeixam não sobre o mundo, mas sobre o corpo com suas aberturas e em estado de gestação. Trata-se de uma imagem que, além de comunicar com outros poemas em que ela aparece, concretizando e expandindo, assim, o estado de união que caracteriza corpo, mundo e poema na poética herbertiana, configura-se no início de Do mundo, ao que parece, como uma espécie de limiar no processo de transmutação do corpo-mundo, uma vez que, sobretudo a partir do poema supracitado, abre-se à gênese de uma forma-mundo. Esta, por sua vez, é convocada já nos versos em análise, por referências que remetem à gênese da terra, como as águas e a oposição luz-obscuridade. Entretanto, são nos poemas subsequentes que integram as demais partes de Do mundo que essa imagem emerge com força e intensidade em seu processo de desenvolvimento. É o que analisaremos a seguir.

\section{Da gênese do mundo}

Assim como no mito da criação a gênese do universo se dá pelo verbo, arriscamos afirmar que a palavra-nome na obra em questão é a partícula, que dá origem ao mundo, além de possuir uma potência tal que cria e envolve o próprio universo, como sugere o quarto poema da primeira parte da obra:

Se é uma criança, diz: eu cá sou cor-de-laranja.

Crianças de pensamento.

Sou amarela.

E pela força apenas se concentram as frutas

por todos os lados iluminadas

a vento, a oxigênio. [...]

O mistério é só este: primeiro são cor de pólen, transfundem-se depois em palavras siderais, botânicas.

As frutas adoçam-se.

Sacode-se a árvore do ar: eu cá sou de plutônio, chamejo, caio.

Os dias separam-se das suas trevas internas. ${ }^{8}$

${ }^{8}$ HELDER, 2006, p. 484-485. 
Nesses versos, não é fortuita a escolha da criança como imagem privilegiada em um poema que integra o conjunto de abertura do livro. Sobretudo na primeira parte de Do mundo há inúmeras referências a esse ser que, segundo Maria Lúcia Dal Farra, "indica a enunciação do "conhecimento informulado". . ${ }^{9}$ Imersa no silêncio inocente das palavras que se lhe apresentam como mundos desconhecidos, a criança comportase à maneira herbertiana com a linguagem. Isto é, recria esta e cria o seu próprio universo. Nos versos de $\mathrm{HH}$, a própria criança torna-se produto da linguagem, "Crianças de pensamento". Pouco importa sobre a verdade evocada pelas palavras que afirmariam a sua cor: "laranja", "amarelo", "polén", "plutônio". Importa que cada palavra volta-se sobre si mesma para criar não uma, mas múltiplas "verdades", múltiplas realidades; tantas quantas lhes forem requeridas. A palavra é a força que move, transforma e cria o mundo. É a gênese deste. É a partir dela que "[...] se concentram as frutas / por todos os lados iluminadas / a vento, a oxigênio", ${ }^{10}$ fluidos que remetem à própria ideia de fluxo, de ausência de materialidade do conceito e, também, ao sopro da criação essencial ao existir. Assim como no mito da gênese do planeta Terra, o mundo nasce pelo poder da palavra, em $\mathrm{HH}$, é ela a força criadora do universo.

Entretanto, enquanto no mito as palavras determinam a ordem no mundo por meio da nomeação e, consequentemente, da separação, "3. E disse Deus: Haja luz. E houve luz. 4. E viu Deus que era boa a luz; e fez Deus separação entre a luz e as trevas", ${ }^{11}$ em HH elas "transfundem-se [...] em palavras siderais, botânicas", ${ }^{12}$ isto é, elas promovem o encontro, a fusão, o fluxo entre elementos, o que é, portanto, contrário ao imperativo divino. Se no mito a separação entre dia e noite é indício da imposição de uma ordem ao mundo, no poema a separação do dia e das "trevas internas" é a evidência de uma expansão da realidade em criação que se dirige ao infinito e ao caos, já que se trata de uma gênese às avessas do universo. $\mathrm{O}$ ato de nomear, diferente do mito, não determina separação, mas movimento, devir, e este caracteriza-se tanto pela separação, quanto pela fusão de uma coisa na outra, assim como sugerem os versos:

\footnotetext{
${ }^{9}$ DAL FARRA, 1986, p. 129.

${ }^{10}$ HELDER, 2006, 485.

${ }^{11}$ ALMEIDA, 1995, p. 3.

${ }^{12}$ HELDER, 2006, p. 485.
} 
Se perguntarem: das artes do mundo? [...]

$\mathrm{E}$ os dias atravessam as noites até aos outros dias, as noites

caem dentro dos dias - e eu estudo

astros desmoronando, mananciais, o segredo". ${ }^{13}$

Na realidade poética, a condição evolutiva dos elementos que dão origem às coisas e aos seres comunga com a própria condição da palavra que "transfunde-se em sideral e em botânica", de modo que impera a lei da metamorfose tanto para o mundo em evolução, quanto para a palavra que o cria. "Cada palavra, mas também cada coisa [...], é assim como um centro de forças irradiantes que comunicam umas com as outras", ${ }^{14}$ fundem-se e separam-se, recriando-se. A linguagem cria o mundo e o mundo recria a linguagem:

Quero um erro de gramática que refaça

na metade luminosa o poema do mundo, e que Deus mantenha o oculto na metade nocturna o erro do erro:

alta voltagem do ouro, bafo no rosto. ${ }^{15}$

Em sua obra A lógica do sentido, Deleuze dedica-se com especial afinco a essa questão na série "Da gênese estática ontológica", em que corrobora a ideia de força criadora da palavra e a sua habilidade de criar e se tornar coisas, realidades, mundos:

No limite, uma qualquer coisa $=\mathrm{X}$ comum a todos os mundos. Todos os objetos + X são "pessoas". Elas são definidas por predicados, mas estes predicados não são mais os predicados analíticos de indivíduos determinados em um mundo e a operar a descrição destes indivíduos. Ao contrário, são predicados que definem sinteticamente pessoas e abrindo-lhes diferentes mundos e individualidades como variáveis ou possibilidades [....$^{16}$

\footnotetext{
${ }^{13}$ HELDER, 2006, p. 492.

${ }^{14}$ RUBIM, 2012, p. 16.

${ }^{15}$ HELDER, 2006, p. 519.

${ }^{16}$ DELEUZE, 2009, p. 118-119.
} 
$\mathrm{Na}$ explicação do filósofo, a composição do ser está inclusa na composição do mundo, já que $\mathrm{X}$, aqui compreendido como a palavra, é comum a todos os mundos e é parte integrante da pessoa/objeto. De igual maneira, o ser/objeto é definido pelos predicados, que, de certo modo, também participam da construção dos mundos que se abrem aos indivíduos e a elementos materiais. Desse modo, o ser e o mundo são produtos da linguagem, do mesmo modo que esta encontra nesses a manifestação de sua materialidade, como o próprio Deleuze sugere: "Não é menos verdade, entretanto, que Deus ${ }^{17}$ cria o mundo antes que as mônadas e que o expresso não se confunde com a expressão, mas insiste ou subsiste"; "Os nomes próprios também são indicadores ou designantes, mas de uma importância especial porque são os únicos a formar singularidades propriamente materiais". ${ }^{18} \mathrm{~A}$ argumentação do filósofo é respaldada pela análise que realiza das obras de Lewis Carroll Alice no País das Maravilhas, e Através do Espelho e o que Alice Encontrou por Lá, as quais possuem pontos de convergência com a estética de $\mathrm{HH}$. Em ambas, a protagonista Alice adentra outro universo, que, de algum modo, está ligado tanto à singularidade da personagem, enquanto sujeito, e ao seu conhecimento "o mundo é realmente o 'pertencer' do sujeito, o acontecimento se tornou predicado, predicado analítico de um sujeito" 19 -, quanto à linguagem. Uma das referências de Deleuze usadas para embasar o problema proposto entre esta e o mundo é o diálogo estabelecido entre Alice e Humpty Dumpty, em que este questiona a fixidez do sentido para as palavras: “"Quando eu uso uma palavra', disse Humpty Dumpty num tom bastante desdenhoso, 'ela significa exatamente o que quero que signifique: nem mais nem menos. "'. ${ }^{20} \mathrm{O}$ diálogo de Humpty Dumpty põe em evidência um dos problemas que desestabiliza o universo de Alice e a arrebata para uma outra realidade: a memória das palavras; problema que atravessa a linguagem com a qual Alice se relaciona no mundo. Sua viagem é, antes de tudo, uma viagem ao caos, ao vazio das convenções, a um lugar arbitrário em relação à ordem estabelecida pelos homens, já que os seres que habitam o "outro lado do espelho" ou o "outro país" se organizam de acordo com outros processos de linguagem e, portanto, estabelecem outra forma de relação com o mundo. Problema esse que encontra repouso na

\footnotetext{
${ }^{17}$ Entendemos Deus no contexto do excerto citado como metáfora da linguagem.

${ }^{18}$ DELEUZE, 2009, p. 114.

${ }^{19}$ DELEUZE, 2009, p. 115.

${ }^{20}$ CARROLL, 2010, p. 245.
} 
poesia de $\mathrm{HH}$, visto que o leitor desta enfrenta questões similares às de Alice e mergulha em um universo que lhe é completamente "estrangeiro", um mundo onde há a falência dos nomes e das palavras:

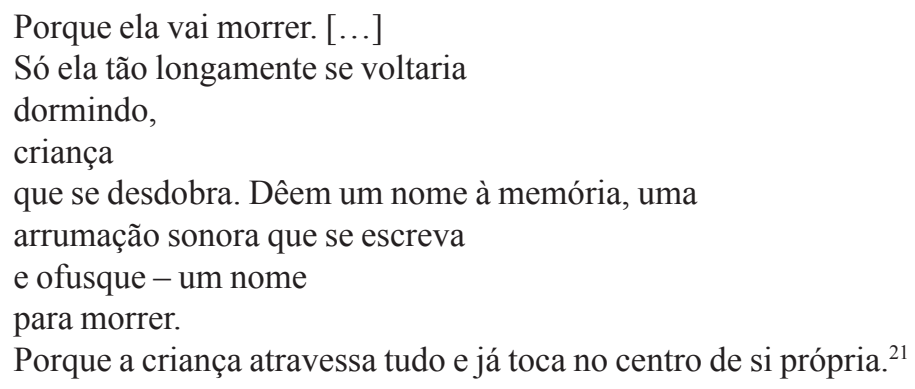

Nesses versos, é sugestiva a relação entre o pronome pessoal "ela" e a memória - imagem última que, em uma possível leitura, parece conter uma função genesíaca, pois gesta a criança-palavra que romperá no mundo. A impossibilidade de se determinar o sujeito "ela" coloca em suspensão o sentido, de modo que o pronome se abre tanto à palavra quanto à memória, referências sobre as quais convergem os demais elementos do poema e põem em evidência o problema que há em sua própria relação. Assim como em Alice, no poema, a memória sofre a morte das palavras, já que recebe um nome escrito cujo destino é determinado no ato de sua criação, a morte. Nesse caso, as palavras, em HH, ao modo do que ocorre no mundo de Alice, perdem seu sentido comum e, como salienta António Guerreiro introduzem "uma zona de sombra e de ilogicidade na linguagem. Este discurso infinito e exasperado cort[a] [...] os vínculos dialéticos com a representação (a mimesis) e produz um excesso cognitivo"; 22 um mundo novo:

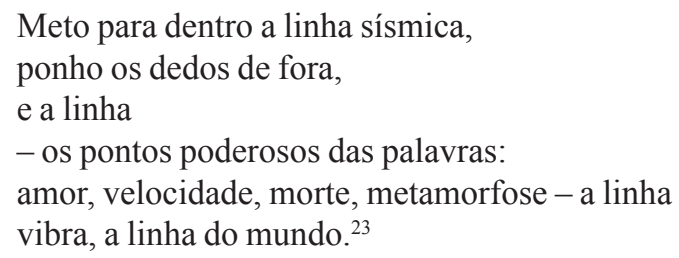

\footnotetext{
${ }^{21}$ HELDER, 2006, p. 489.

${ }^{22}$ GUERREIRO apud MAFFEI, 2007, p. 23.

${ }^{23}$ HELDER, 2006, p. 509.
} 
O nó temático aqui defendido é concebido não apenas pela possibilidade de leituras pontuais de poemas isolados, mas é fruto da convergência de diversos enfeixamentos de imagens siderais e também de referências abundantes aos elementais necessários à formação do universo. Do mundo é uma poética, sobretudo, do fluxo, da água, do ar, do fogo, da terra e do verbo, imagens essas recorrentes em quase todos os poemas. Trata-se, de acordo com palavras de João Décio, de uma "poesia elemental". ${ }^{24}$ De um espaço caracterizado pelo vazio das formas em vias de transformação, as quais se processam por um movimento que remete à gênese do mundo, que se dá pela linguagem; hipótese que encontra respaldo na possível leitura do poema a seguir:

Esta coluna de água, bastam-lhe o peso próprio, $\mathrm{o}$ ar à roda, ter sido olhada não como imagem de uma garrafa mas como concreta e contínua forma; ou subir na memória de alguém que, vendo-a, sabe que vai desaparecer e arrebata, num afluxo molecular, não o nome dela: coluna ou garrafa ou centro do planeta, mas ter sido olhada completamente uma vez, ela, e na voltagem da luz transferir-se para outra zona: ser uma garrafa luzindo

de ar e água e quietude; ou que se não transfira, e seja então como se a roçasse Deus por cima de tudo: linguagem, biografia, pensamento, eternidade prumo de água com raios, vidro com raios, coisa - e salvando-se da ordem dos elementos gerais:

Deus também, e as linhas direitas por onde escreve torto: moléculas, mais nada, perenes,

${ }^{24}$ DÉCIO, 2002, p. 14. 


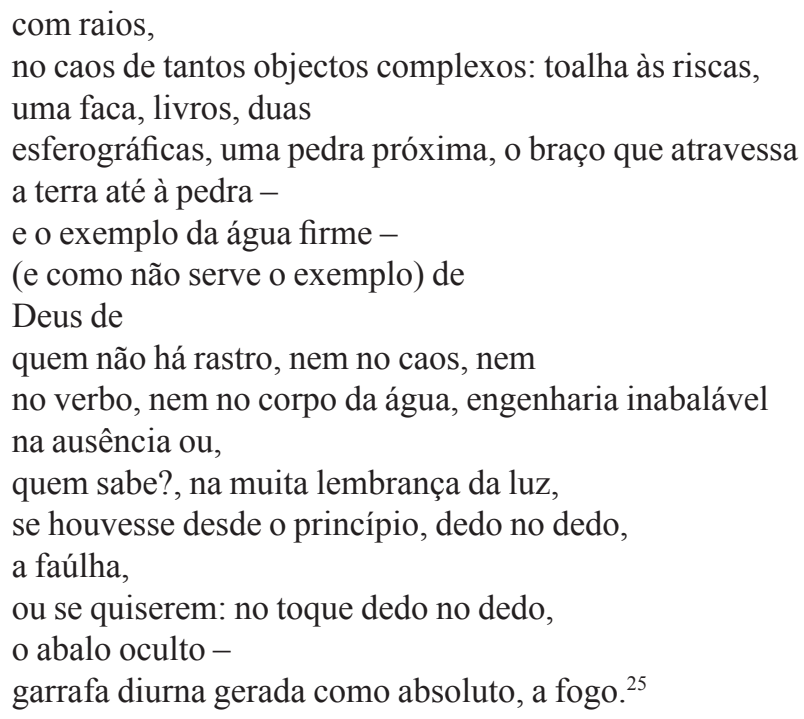

Imagem emblemática neste poema, a garrafa é o nó temático sobre o qual enfeixam-se as demais imagens e referências, de modo que se torna inadequado limitar sua leitura a algumas poucas interpretações. Seu sentido apresenta-se em suspensão, uma vez que sua associação com predicados e imagens aparentemente ilógicos desencadeia uma série de possibilidades de significados. Entretanto, duas perspectivas possíveis, ela pode assumir. A primeira delas reporta à materialidade de um objeto, isto é, a referência a esse substantivo evoca-o em sua condição de objeto da realidade, "concreta e contínua forma". Observada sob a lógica dessa convenção humana, a garrafa é um elemento cujo significado se esgota em si mesmo, em sua funcionalidade: "bastam-lhe o peso próprio", ${ }^{26}$ já que se trata de uma forma física cujo destino se limita ao abrigo de uma "coluna de água", ou de um líquido qualquer. Em uma segunda, ela pode ser concebida como imagem que, ao ser "olhada completamente" e apreendida pelo poeta, "sobe à memória" e perde a sua condição conceitual, o seu nome, para tornar-se "uma garrafa luzindo de ar e água / e quietude", ${ }^{27}$ imagem essa que alude ao mundo no início de sua criação, repleto do vazio de seus próprios fluxos, o ar e a água, e da permanência do silêncio.

\footnotetext{
${ }^{25}$ HELDER, 2006, p. 493-494.

${ }^{26}$ HELDER, 2006, p. 493.

${ }^{27}$ HELDER, 2006, p. 493.
} 
Em um ensaio intitulado "Poesia e Arte Poética em Herberto Helder", João Décio propõe uma análise, sob uma perspectiva estruturalista, sobre a relação entre a poesia e a coisa, a palavra e o objeto em $\mathrm{HH}$. Segundo acredita, tais relações são a evidência de um "verdadeiro processo de redescoberta do mundo", de maneira que a "presente poesia conhece e contempla o mundo". ${ }^{28}$ Para ele, a ausência de um ser na linguagem, ou de uma referência fixa para o nome, é uma "tentativa de nomear o mundo, $[\ldots]$. Com a palavra e o poema, com o poema, com a criação e a recriação, é possível afirmar que [Herberto Helder] está atento ao código e à decodificação de um mundo, por via das palavras". ${ }^{29}$ Acreditamos, entretanto, que no processo de recriação da palavra poética em HH não há, propriamente, uma redescoberta do mundo, tampouco uma nomeação, ou mesmo uma decodificação deste. Trata-se da gênese de uma nova realidade. Aqui o nome garrafa, é (in)definido pelos inúmeros predicados que se the abrem, de modo que estes, aliados àquilo que complementam, criam novos espaços, isto é, novos mundos e universos. Como imagem poética, a garrafa deixa a sua concretude física para "transferir-se para outra / zona"; 30 tornar-se um mundo em vias de transformação, uma realidade outra que se materializa pela ação da linguagem. Essa gênese é tematizada no próprio poema, já que os elementos com os quais a garrafa interage, água, ar e fogo, são os mesmos descritos na gênese da terra ainda informe, fluidos de natureza inconstante ligados ao movimento, ao devir e à criação do planeta e seu cosmos.

É notório, inclusive, como o mundo que se processa a partir do deslocamento do conceito da garrafa é um espaço que se opõe a Deus nos termos de uma perspectiva deleuzeana. A força divina que se impõe por um "braço que atravessa a terra até a pedra" na sugestiva criação do mundo presente nos versos é a do anticristo, e não a de um Deus que estabelece a ordem. Em uma paráfrase do que diz o próprio poeta, a "água fixa" não é exemplo para as operações que se processam no mundo de $\mathrm{HH}$, uma vez que o Deus presente nestas desaparece em meio ao caos das referências, de modo que não deixa "rastro, nem no caos, nem / no verbo, nem no corpo da água" ${ }^{31}$ Restam apenas as palavras, em sua desordem

\footnotetext{
${ }^{28}$ DÉCIO, 2002, p. 14.

${ }^{29}$ DÉCIO, 2002, p. 24.

${ }^{30}$ HELDER, 2006, p. 493.

${ }^{31}$ HELDER, 2006, p. 494.
} 
significativa, (des)ordenadas segundo a insignificância e a errância dos nomes. A garrafa, nesse caso, "[salva-se] da ordem dos elementos gerais" 32 do mesmo modo que "Deus também", para alçar a origem de todas as coisas. Sua convivência no caos dos nomes, "tantos objectos complexos: toalha às riscas, / uma faca, livros, duas / esferográficas, uma pedra próxima" 33 sugere e ao mesmo tempo encena o devir que transforma as partículas moleculares necessárias à origem do universo. Trata-se das transmutações, possíveis pela ação dos elementais água, ar e fogo, que dão início à formação de outra zona de realidade. É a origem do poema-mundo. O poema se torna a coisa outra.

É relevante, ainda, o destaque conferido ao elemento fogo, última palavra do poema cuja ênfase é intensificada pelo lugar estratégico que ocupa. Isso porque sua ação é essencial não apenas ao início da gênese do mundo, mas às metamorfoses que neste se processam. A obra herbertiana assume o valor de organismo vivo não apenas pelas referências que realiza em relação ao mundo e ao corpo, mas por ser "garrafa diurna em absoluto, gerada a fogo", ${ }^{34}$ isto é, por se tratar de um poema dotado de energia alquímica, cuja linguagem se funde e se confunde com as operações do corpo e do universo, (des)acompanhando-lhes o ritmo, a cadência, os movimentos e as transformações. A gênese do mundo e a organicidade, segundo palavras de António Guerreiro em seu ensaio "A Poesia, Baptismo Atónito", publicado na revista Textos e Pretextos, de outubro de 2012, desenvolvem-se no interior de um "idioma demoníaco que confere às palavras um valor absoluto e coloca a linguagem num contínuo estado de inauguração." "35 Idioma que dá lugar a "todas as metamorfoses, variações, transmutações. É nele que o mundo se torna ilimitado, oferecendo-se em estado de contínua explosão [...]. [A] poesia [...] pode reivindicar [...] não um discurso sobre o mundo, mas um discurso constitutivo de um mundo. ${ }^{36}$

O fogo, nesse caso, é o elemental cuja função é fornecer a energia necessária aos processos constitutivos que põem o mundo em transmutação. É uma força geradora e sustentadora da própria vida, assim como destaca Izabela Guimarães Guerra Leal em sua dissertação

${ }^{32}$ HELDER, 2006, p. 493.

${ }^{33}$ HELDER, 2006, p. 493.

${ }^{34}$ HELDER, 2006, p. 494.

${ }^{35}$ GUERREIRO, 2012, p. 52.

${ }^{36}$ GUERREIRO, 2012, p. 53. 
Doze Nós num Poema: Herberto Helder e as Vozes Comunicantes: “A metamorfose [...] corresponde sempre a uma elevação da potência de vida". ${ }^{37}$ Postos em ação os processos de metamorfoses, mimetiza-se tanto o movimento do mundo, quanto o do corpo.

Em um artigo intitulado "Corpo Velocidade", Rosa Maria Martelo reitera a percepção aqui apresentada:

A obra que procura testemunhar do "indeterminado existente" é aquela que responde à impossibilidade de representação pondo-se a si mesma em evidência, exibindo a sua espessura discursiva. Nesse processo, a sua relação com o mundo é essencialmente metonímica: ela mostra-se como entidade discursiva, como experiência, "amostra-demundo", permite-nos olhá-lo na sua face mais intensa. ${ }^{38}$

$\mathrm{O}$ resultado estético das metamorfoses da poética de $\mathrm{HH}$, nesse caso, é um devir que realiza a pantomima de um mundo orgânico em expansão, que se retrai e se contrai em seu cosmos, como salienta Maffei, "Não me esqueço de que o universo é visto por alguns astrônomos como um organismo que se expande e retrai, ou seja, fluxo e refluxo, ${ }^{39}[\ldots]$ portanto exerce um movimento afim ao primordial, pois se irmana ao movimento do universo [...]", ${ }^{40}$ tendendo a um crescimento que envolve tudo a sua volta: "o poema cresce tomando tudo em seu regaço". ${ }^{41}$

O valor que a garrafa assume enquanto imagem poética é, portanto, superior à sua condição como elemento da realidade concreta. Ao ocupar o lugar da poesia, ela coloca-se acima de qualquer explicação da lógica humana e acima da fixidez dos nomes:

\section{[...] seja então}

como se a roçasse Deus por cima de tudo:

linguagem, biografia, pensamento, eternidade. ${ }^{42}$

\footnotetext{
${ }^{37}$ LEAL, 2008, p. 74.

${ }^{38}$ MARTELO, 2006, p. 52.

${ }^{39}$ Em seu comentário, Maffei refere-se aos versos "Pus-me a saber: estou branca sobre uma arte / fluxa e refluxa: a lua nasce da roupa fria, sai-me a cabeça / das zonas da limalha, / dos buracos fortes da água" (HELDER, 2004, p. 484).

${ }^{40}$ MAFFEI, 2007, p. 108-109.

${ }^{41}$ HELDER, 2006, p. 26.

${ }^{42}$ HELDER, 2006, p. 493.
} 
Isto é, não se pode confiná-la à simples ideia da representação de lugares comuns, pois se trata de um mundo. António Guerreiro corrobora, de certo modo, a leitura aqui apresentada em "A Poesia, Baptismo Atónito": "O poema é, assim, um pensar a origem, um ir para além da linguagem dos homens e da sua história". ${ }^{43}$ A imagem da garrafa concentra, portanto, um poder tal que é a expressão de todas as formas, de todos os sentidos, de todas as interpretações possíveis. É a gênese de tudo; o mundo-poema, o poema do mundo.

Um outro poema em que a relação entre o mundo, a palavra e a linguagem se faz evidente encontra-se na terceira parte da obra aqui analisada. Nele, frase e mundo são manejados por uma força criadora:

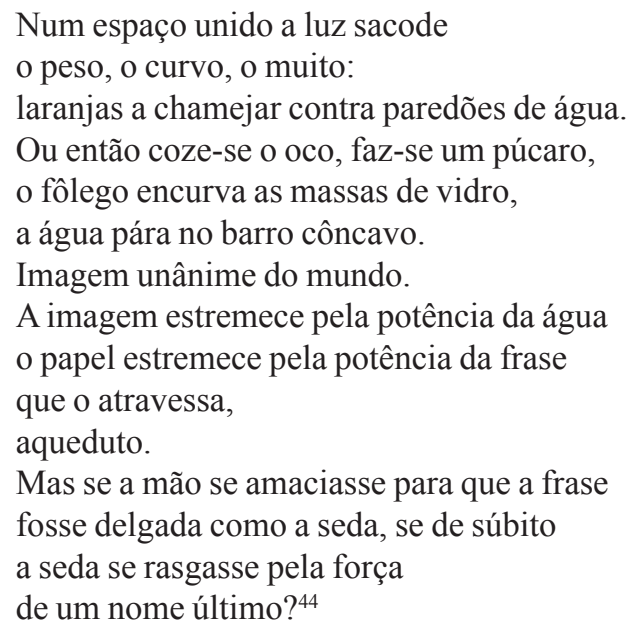

A leitura dos versos transcritos, quando realizada a partir do diálogo entre imagens que nele ganham destaque com imagens de outros textos poéticos da obra de Herberto Helder, legitima certas impressões que ganham relevo na poesia de $\mathrm{HH}$, como é o caso da pantomima de uma gênese de um mundo em processo e do paralelismo estabelecido entre este e a linguagem poética. Nesse poema, a ausência de uma nomeação que dê forma à realidade - "o peso, o muito, o curvo" -, a presença da luz, a força dos fluxos, a potência criadora do vazio de um espaço em sua gênese - "coze-se o oco" - evocam uma forma informe que se processa

\footnotetext{
${ }^{43}$ GUERREIRO, 2012, p. 52.

${ }^{44}$ HELDER, 2006, p. 511.
} 
a partir do caos inerente ao princípio de todas as coisas: trata-se de uma "imagem unânime do mundo" que ganha organicidade, movimento e energia na medida em que essas características também se fazem condição para a linguagem poética. Relação essa cujo próprio poema destaca:

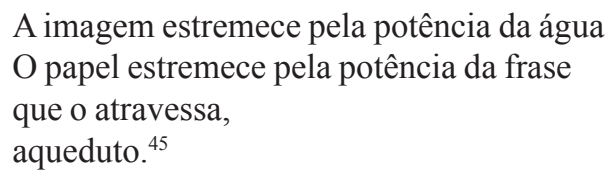

A mão do poeta que molda a frase é também a mesma que molda o mundo pela força que há nos nomes, e, assim como estes são dotados de potência metamórfica, esse também o é. Como reitera Ana Lúcia Guerreiro em seu artigo "A 'Antropófaga Festa'. Metáfora para uma ideia de poesia em Herberto Helder" (2009), "Mais do que uma via para o conhecimento, o poema abre-se como espaço lúdico resultante do "prazer de maquinar o universo numa estrita / organização de linhas vividas em 'iminência', de imagem em imagem."”. 46

Se a transição da primeira parte de Do mundo (HELDER, 2006) para a segunda é caracterizada por um poema que coloca em evidência um corpo que é também uma espécie de porta de acesso ao mundo, a passagem da terceira parte para a quarta põe em relevo a última componente da tríade que se apresenta como objeto de nossa pesquisa: o poema em sua condição de obra, de criação:

A ascensão do aloés: vê-se,

Fica-se bêbado. É tão leve o esperma.

De noite os cabelos crescem tanto que neles se amarra a cabeça, Crescem a cada pancada do sangue,

Cada sopro.

Num tronco escreve-se o nome do mundo,

A ferida do mundo,

A seiva freme nos dedos.

Que tocam, os dedos, no pênis e nos testículos:

e sente-se em baixo o furor

do ouro.

Com erros misteriosos escreve-se o poema primeiro do tempo:

${ }^{45}$ HELDER, 2006, p. 511.

${ }^{46}$ GUERREIRO, 2009, p. 15. 


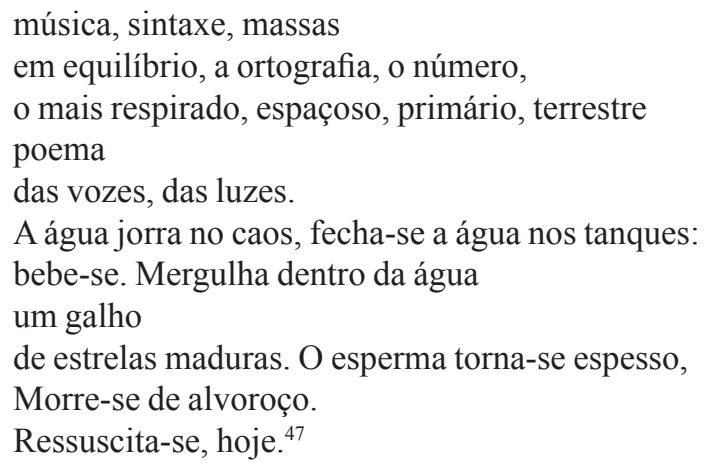

Nos versos supracitados, a figuração do mundo em nome constitui-se, mais uma vez, como nova transmutação, de modo que essa imagem abre-se a um espaço ainda mais amplo, que a comporta: o poema. Envolta em uma atmosfera da origem, que se dá tanto pelo corpo - como sugerem as imagens do sangue e do esperma - quanto por uma gênese que reporta à criação do universo - haja vista a presença dos fluidos, como a água e o sopro - a palavra poética coloca-se como uma ferida no mundo, sendo também, nesse caso, a ferida do corpo. É a palavra em sua força produtiva que detém, assim como elucidam os versos finais, o poder de matar e de ressuscitar. É ela que assassina e vivifica o corpo, é ela que destrói e cria o mundo. Em "A faca não corta o fogo: contextos poéticos de uma biografia" (2009), João Amadeu Oliveira Carvalho da Silva põe em relevo essa característica da palavra herbertiana, ao afirmar que, em decorrência dela:

A morte deixa de assumir a centralidade [...] e passa a ser incorporada no acto criador, absorvida como estado de depuração necessária. Afinal, para lá da morte, preparada tão atenta e persistentemente pelo poeta, existe uma realidade que a ultrapassa e que de imediato [é] evidenciada e concretizada na imagem [...] "redivivo". ${ }^{48}$

O pensamento deleuzeano novamente é corroborado pelo enfeixe temático de Do mundo, já que a palavra, ou o nome, é a via pela qual se finaliza e reinicia a vida, seja ela do corpo, do mundo ou do próprio

\footnotetext{
${ }^{47}$ HELDER, 2006, p. 511-512.

${ }^{48}$ SILVA, 2009, p. 73.
} 
sentido. E é a reiteração dessa premissa uma das componentes de sustentação temática (se se pode considerar temas na poesia de $\mathrm{HH}$ ) de Do mundo, já que os poemas dessa obra poética seguirão, no que se refere à comunicação dessas três imagens em um movimento de eterno retorno do mesmo que se estabelece pela diferença, de modo que cada aparição do corpo, do mundo e da palavra, ou do poema, exige o assassinato e a vivificação dessas imagens. Retorno esse que, como tratado anteriormente, se dá pela diferença. Do mundo, nesse sentido, parece recolher os principais eixos de convergência de $O$ corpo o luxo a obra e espiralizá-los em um movimento de busca da expansão de um cosmos em aberto. Se $O$ corpo o luxo a obra convoca um corpo poético a se manifestar em sua condição orgânica e viva, Do mundo expandese em um movimento incessante que integra uma realidade outra, um universo outro, um mundo que se orienta pela força da palavra poética.

\section{Referências}

CARROLL, Lewis. Aventuras de Alice no País das Maravilhas e Através do Espelho e o que Alice Encontrou por Lá. Rio de Janeiro: Zahar, 2010.

DAL FARRA, Maria Lucia. A Alquimia da Linguagem: Leitura da Cosmogonia Poética de Herberto Helder. Lisboa: Imprensa Nacional / Casa da Moeda, 1986.

DÉCIO, João. Poesia e Arte Poética em Herberto Helder e Outros Estudos. Santa Catarina: Edifurb, 2002.

DELEUZE, Gilles. A Lógica do Sentido. São Paulo: Perspectiva, 2009.

GUERREIRO, Ana Lúcia. “A 'Antropófaga Festa'. Metáfora para uma Ideia de Poesia em Herberto Helder”. In: MACEDO, Ana Gabriela; SOUSA, Carlos Mendes de. (Org.). Diacrítica. Minho, FCT, n. 23/3, 2009.

GUERREIRO, António. “A Poesia, Baptismo Atónito”. Textos e Pretextos: Herberto Helder, n. 17, outubro de 2012.

HELDER, Herberto. Edoi Lelia Doura: Antologia das Vozes Comunicantes. Lisboa: Assírio \& Alvim, 1985.

HELDER, Herberto. O Ofício Cantante. Lisboa: Assírio \& Alvim, 2009. 
HELDER, Herberto. Ou o Poema Contínuo. São Paulo: Girafa, 2006.

LEAL, Izabela Guimarães Guerra. Doze Nós num Poema: Herberto Helder e as Vozes Comunicantes. 2008. 152 f. Tese (Doutorado em Letras Vernáculas) - Faculdade de Letras, Universidade Federal do Rio de Janeiro, Rio de Janeiro, 2008.

MARTELO, Rosa Maria. "Corpo, Velocidade e Dissolução (de Herberto Helder a Al Berto)". In: AMARAL, Ana Luísa; FREITAS, Marinela; CARVALHO, Paulo Eduardo (Org.). Cadernos de Literatura Comparada 3/4: Corpo, Identidades. Porto: Instituto de Literatura Comparada Margarida Losa da Faculdade de Letras do Porto, 2001. p. 164-199.

MAFFEI, Luis Claudio de Sant'Anna. Do Mundo de Herberto Helder. 2007. 503 f. Tese (Doutorado em Literatura Portuguesa) - Faculdade de Letras da Universidade Federal do Rio de Janeiro, Rio de Janeiro, 2007. SILVA, João Amadeu Oliveira Carvalho da. "A Faca não Corta o Fogo: Contextos Poéticos de uma Biografia". In: MACEDO, Ana Gabriela; SOUSA, Carlos Mendes de. (Org.). Diacrítica. Minho, FCT, n. 23/3, 2009. 
